\title{
KREATIVITAS DAN KOMPETENSI GURU SEKOLAH DASAR
}

\author{
Ahmad Fahmi Ayyubi \\ Program Studi Pendidikan Guru Sekolah Dasar \\ Fakultas Keguruan dan Ilmu Pendidikan \\ Universitas Nahdlatul Ulama Sidoarjo \\ Email: begk2018@gmail.com
}

\section{Pengantar}

Pasti di benak dan pikiran semua orang tidak terlepas dari kata "guru". Guru merupakan salah satu orang tua yang berjasa penting bagi murid-murid dari zaman sekarang, zaman dahulu dan zaman-zaman yang akan muncul generasi-generasi yang akan datang. Seorang ilmuwan ada yang mengatakan guru merupakan ujung tombak keberhasilan dalam membentuk generasi penerus bangsa yang berkualitas. Bagi seorang guru harus melihatkan kemampuan-kemampuan yang dimiliki seorang guru dan memperlihatkan sikap-sikap professional sebagai guru. Sebagai seorang guru juga wajib menyemangati dan mendorong peserta didik untuk mengetahui isi pembelajaran tersebut dan meningkatkan rasa ingin tahu peserta didik tersebut agar peserta didik tersebut lebih rajin belajar, lebih semangat mendengar, menulis, memahami, dan lebih dekat dengan pendidik, sehingga peserta didik bisa mendapatkan apa yang di inginkan oleh perasaan ke ingin tahuan tersebut.

Guru juga harus memantapkan minat dan semangat siswa, karena ini berperan penting juga pada peserta didik agar dalam pencapaian, keberhasilan, kesuksesan pada peserta didik bisa berhasil dalam tujuan pembelajaran tersebut, guru juga harus berinteraksi, berkomunikasi, saling bekerjasama, saling bertukar pendapat antar guru-guru lain, gurru sesama sekolah atau guru yang berada di sekolahan lain. Maka dari itu guru berperan penting sekaligus penanggung jawab dalam proses pembelajaran.

Guru adalah seorang yang tepat bagi orang mencari ilmu. Dia mampu melaksanakan proses pembelajarannya dengan baik dan dapat mendorong dan membantu perkembangan kekreatifan siswa dengan berupaya mendorong atau menciptakan lingkungan pembelajaran yang kondusif bagi peserta didik. Karena kreatifitas merupakan suatu yang dimiliki semua orang yang pemikiran dan kelakuan yang berbeda-beda dan itupun tidak semua orang mengetahui atau tahu apa yang dipikirkan orang tersebut. Karena itu guru harus mengetahui karakterkarakter peserta didik itu salah satu tugas guru yang sangat penting bagi guru. Jadi, guru harus tahu peserta peserta didik yang kreatif, seddang kreatif sampai dengan 
peserta didik yang kurang kreatif dalam pembelajaran. Kaarena di setiap anak lahir atau masuknya siswa baru pasti itu ada yang berpotensi kreatif dan ada juga yang kurang dalam berpotensi kreatif. Guru memberi pembelajaran kreatif pada murid supaya peserta didik agar bisa mengembangkan kekreatifitasannya yang itu berarti penting bagi peserta didik untuk aktif dalam membangun, membangkitkan semangat dalam kekreatifitasannya pada diri peserta didik. Mengembangkan kekreatifitasan siswa dalam pembelajaran itu sangat penting dan berarti bahwa pembelajaran kreatif itu juga sama dengan mengembangkan kompetensi dan memenuhi standar proses pembelajaran.

\section{Kompetensi guru sekolah dasar}

Kompetensi guru merupakan salah satu aspek yang terpening karna guru dituntut mampu merenacanakan dan melaksanakan proses pemvelajaran, menilai proses dan hasil pembelajaran, serta melakukan pembimbingan dan pelatian pada pesrta didik. Kompetensi di pengaruhi oleh berbagai faktor yang saling tekait sau sama lain, yang pada hakikatnya dapat di kelompokkan kedalam faktor internal dan eksternal. Salah satu fakto internal yang menentukan adalah kreatifitas.

Segala pengetahuan, keterampilan, dan prilaku yang dimiliki, dihayati, dan dikuasai oleh seorang pendidik dalam melaksanakan tugas pembelajaran itu yang dinamakan kompetensi guru sekolah dasar (UU No. 14/2005 tentang guru dan dosen pasal 1 butir 10). Kompentasi inti guru SD meliputi : (1) kompetensi pedagogik, (2) kompetensi kepribadian, (3) kompetensi sosial, dan (4) kompetensi profesional yang diproleh melalui pendidikan.

Guru merupakan tenaga pendidik yang bertugas merencanakan dan melaksanakan proses pembelajaran, menilai hasil pembelajaran, melakukan pembimbingan dan pelatihan pembelajaran (UU No. 20/2003 tentang sisdiknas, pasal 39). Oleh karena itu, untuk mewujudkan tujuan pendidikan nasional haruslah seorang guru wajib memiliki kualifikasi akademik, kompetensi, setifikat pendidik, sehat jasmanai dan rohani.

Kompetensi profesional meliputi : (1) menguasai materi, struktur, konsep, dan pola pikir keilmuwan yang mendukung mata pelajaran yang diampu; (2) menguasai standar kompetensi dan kompetensi dasar mata pelajaran atau bidang pengembangan yang diampu; (3) mengembangakan materi pembelajaran yang ampu secara kreatif; (4) mengembangkan keprofesionalan seecara berkelanjutan dengan melakukan tindakan reflektif; (5) memanfaatkan teknologi informasi dan komunikasi untuk mengembangkan diri.

Sebagai seorang guru harus berpondasi pada sifat disiplin. Baik disiplin dalam management waktu maupun disiplin dalam hal yang lain. Dengan begitu guru menerapkan prinsip tersebut kepada peserta didik, agar semua peserta didik 
bisa memiliki jiwa kepemimpinan. Guru juga harus menjaga etika sebagi tenaga pendidik. Karena mendidik adalah tanggung jawab setiap orang yang terdidik.

Membangun indonesia dengan penndidikan. Kita percaya bahwa dengan adanya pendidikan dan generasi penerus bangsa akan memajukan bangsa ini dengan mengamalkan apa yang telah di pelajari di bangku sekolah serta menghargai jasa guru-gurunya. Bijaksana dan pantang menyerah adalah kunci kesuksesan.

\section{Kreativitas}

Kreativitas sebagai faktor mental manusia telaah lama diperbincangkan oleh para ahli, namun sampai saat ini penerapannya di sekolah indonesia belum seperti apa yang diharapkan. Dengan melatih pesrta didik untuk berpikir dan menemukan suatu pengetahuan, tanpa di sadari seorang Pendidik termasuk sudah menekankan pada pengembangan berpikir logis dan konvergen (berpikir ke satu arah) seorang siswa tersebut. Kurangnya kreativitas guru dalam menanggapi, memperhatikan dan mengembangkan kemampuan peserta didik untuk berpikir divergen (ke segala arah) dan memecahkan masalah secara kreatif. Salah satu faktor kurangnya kekreativan seorang guru adalah waktu pembelajaran yang terbatas, dan terlalu sulitnya beban belajar peserta didik dalam kurikulum.

Untuk menjadi seorang guru diperlukan adanaya kemampuan kreatif yang merupakan aspek penting yang harus dimiliki seorang guru jika mengharapkan terciptanya adanya lingkungan belajar yang aktif dan kondusif (terkendali). Dengan adanya lingkungan belajar yang aktif dan kondusif (terkendali) siswa menjadi terdorong untuk menjadi peserta didik yang kreatif. Untuk memajukan dunia pendidikan diperlukan adanya tingkat kemampuan kreatif yang tinggi dari seorang guru dalam melakukan kegiatan belajar mengajar. Kekreativitasan peserta didik tergantung pada seorang guru. Kekreativan peserta didik hanya bisa dikembangkan apabila gurunya kreatif. Guru yang kreatif memiliki kemampuan menyampaikan ilmu pengetahuan kepada para peserta didiknya secara kreatif, sehingga peserta didik menggemari ilmu pengetahuan yang diajarkan kepadanya dan membuat pesrta didik dapat berpikir secara kreatif pula.

Kreativitas tidak terbatas pada tingkat usia, jenis kelamin, suku, bangsa,dan kebudayaan tertentu (semiawan 1984) setiap orang memiliki kemampuan kreatif, karna kreatifitas merupakan atribut bagi semua orang.kreatifitas yang dimiliki manusia lahir bersama dengan lahirnya manusia itu dan dapat muncul serta terwujud dalam semua bidang kegiatan manusia (munadar, 1988). Namun, orang yang kreatif memiliki ciri-ciri kepribadian yang secara signifikan berbeda dengan orang kurang kreatif.

Munadar (1988) mengemukakan bahwa kreativitas merupakan ungkapan unik dari keseluruhan kepribadian sebagai hasil intraksi individu dengan lingkungannya yang tercermin dalam pikiran, prasaan, sikap, atau prilakunya. 
Kreativitas sebagai seuatu proses, bahwa setiap orang menemukan hubungan2 yang baru, untuk mendapatkan jawaban, metode, atau tata cara baru dalam menghadapi suatu masalah tidak selalu dilakukan secara spontan tpi memerlukan proses berpikir. karya kreatif tidak lahir karna kebetulan, melainkan melalui serangkaian proses kreatif yang menuntut kecakapan, keterampilan, dan motivasi yang kuat.

kreativitas adalah seautu proses yang menghasilkan proses yang baru. kreativitas dapat berkembang karna adanya dorongan internal dalam individu berupa : (1) keterbukaan terhadap pengalaman, (2) kemampuan untuk menilai situasi sesuai dengan patokan pribadi, dan (3) kemampuan untuk bereksperimen, untuk bermain dengan konsep-konsep. namun, dorongan internal ajah tidak cukup, perlu stimulus dan respon yang dapat mendorong seseorang untuk berfikir kreatif.

Maka dari penjelasan dapat kita simpulkan bahwa semakin guru SD maka akan tinggi pula kompetensinya : sebaliknya, semakin rendah kreativitas guru SD maka akan semakin rendah kompetensinya

\section{Pendidikan Guru SD di Indonesia}

Dunia pendidikan adalah bagian yang tak terpisahkan dari semua orang atau terkhususkan pada peserta didik. kualitas seorang pendidik atau guru yang dibutuhkan oleh pada bangsa indonesia pada masa depan adalah mampu menghadapi persaingan yang semakin ketat dengan bangsa lain yang ada dunia. Kualitas masyarakat indonesia tersebut dapat melalaui penyelenggaraan pendidikan yang bermutu oleh pendidik profesional. Dibawah ini adalah diagram presentase jumlah guru dan tenaga pendidik di Indonesia sebagai berikut:

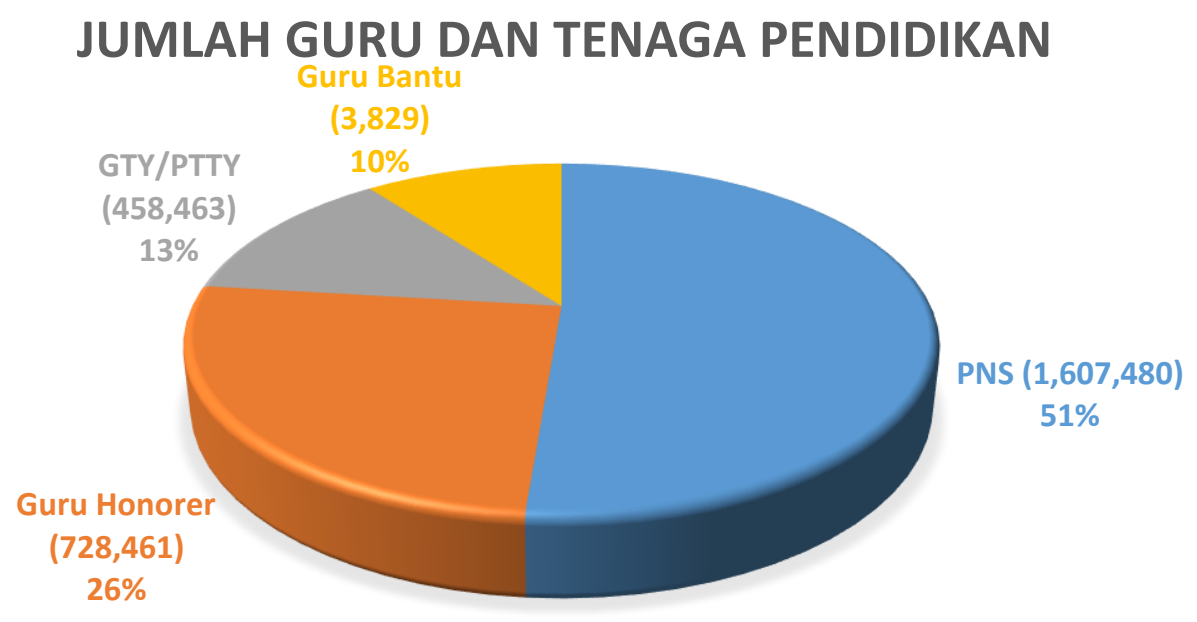


Pada diagram lingkaran di atas, dapat dilihat bahwa jumlah guru yang didominasi oleh Guru yang berstatus PNS dengan jumlah 51\%, kemudian sisanya Guru Honorer 26\%, GTY/PTTY sebanyak 13\% dan yang paling terakhir adalah jumlah guru bantu yang hanya $10 \%$.

\section{Penutup}

Kompetensi guru adalah segala kemampuan, keterampilan, kekreativan, pengetahuan, dan sikap seorang guru yang dilakukan secara sadar guna melakukan tugas wajib bagi seorang pendidik untuk mencerdaskan generasi penerus bangsa secara nyata di lingkungan sekolah terhadap warga sekolah dan di masyarakat terhadap warga masyarakat dengan memberikan teladan yang baik.

Kreativitas adalah seautu proses yang menghasilkan proses yang baru. 


\section{REFERENSI :}

Judiani, S. (2017). Kreativitas dan Kompetensi Guru Sekolah Dasar. Jurnal pendidikan dan kebudayaan, 17,1 nd ser.,65-68. Retreived December, 27, 2018, from https://media.neliti.com/media/publications/122796$\underline{\text { ID-Kreativitas-dan-kompetensi-guru-sekolah.Pdf }}$

Maula, I., Asitah, N., Munjidah, A., Nahdiyah, K., Yuniarti, D., Sholichah, S. A., Purnomo, A., Anam, F., Rosyidah, E., Istiqomah, N., \& Qori'ah, S. (2018, May 25). Kontribusi Kreativitas Guru SD dalam Induksi Pembelajaran. http://doi.org/10.17605/OSF.IO/BS795

Maula, I., Mufidah, F.I., Rosyidah, E., \& Purnomo, A. (2017). SD Antawirya Islamic Javanese School Mother is Culture. In Wirausaha Pendidikan Indonesia (Jilid 1). Sidoarjo: Unusida Press.

Nahdiyah, K., Amrina, S., Purnomo, A., \& Rosyidah, E. (2017). SD Taman Pendidikan Islam Porong Iman Kuat Bekal di Akhirat. In Wirausaha Pendidikan Indonesia (Jilid 2). Sidoarjo: Unusida Press.

Qori'ah, S., Sholikhah, S.A., Purnomo, A., \& Rosyidah, E. (2017). MI Progresif Bumi Sholawat dengan Kebenaran Semua Pasti Ada Jalan. In Wirausaha Pendidikan Indonesia (Jilid 3). Sidoarjo: Unusida Press.

Munjidah, A, Zannah, I.P.N., Purnomo, A., Rosyidah, E. (2017). MI Thoriqussalam Berpegang Kepada Rosul. In Wirausaha Pendidikan Indonesia (Jilid 4). Sidoarjo: Unusida Press. 